\title{
AJARAN CATUR GURU DALAM PENGUATAN KARAKTER PESERTA DIDIK
}

\author{
Oleh: \\ I MADE SUARDANA \\ Imadesuardan35@gmail.com \\ Universitas Hindu Indonesia \\ Denpasar
}

Proses review 10-23 April, Dinyatakan Lolos 24 April

\begin{abstract}
This article discusses the world of education in Karangasem Regency, especially in Central Tianyar. There are some deviant attitudes and behaviors such as not obeying school norms, daring to fight teachers, insulting teachers, fighting, destroying government facilities, dishonesty and so on. Seeing this problem, the Middle School One Roof Middle Tianyar intensified learning based on religious values and character. One of the religious teachings used in the process of character building is Teacher Chess. This paper will examine the teacher's Chess learning in strengthening students' character.
\end{abstract}

Keywords: Strengthening Character, Catur Guru

\begin{abstract}
Abstrak
Artikel ini membahas tentang dunia pendidikan di Kabupaten Karangasem, khususnya di Tianyar Tengah. Ada beberapa sikap dan perilaku menyimpang seperti tidak mematuhi norma sekolah, berani melawan guru, menghina guru, perkelahian, merusak fasilitas pemerintah, ketidakjujuran dan sebagainya. Melihat persoalan ini maka SMP Negeri Satu Atap Tianyar Tengah menggencarkan pembelajaran yang berbasis pada nilai agama dan karakter. Salah satu ajaran agama yang digunakan dalam proses pembentukan karakter adalah Catur Guru. Tulisan ini akan mengkaji tentang pembelajaran Catur Guru dalam penguatan karakter peserta didik.
\end{abstract}

Kata Kunci: Penguatan Karakter, Catur Guru

\section{PENDHULUAN}

Pendidikan dalam pembukaan UndangUndang Dasar 1945 pada alenia empat menyebutkan "mencerdaskan kehidupan bangsa". Sejalan dengan itu Undang-Undang Dasar 1945 pasal 31 ayat 1 menyebutkan bahwa tiap-tiap warga Negara berhak mendapatkan pengajaran. Kemudian didalam Undang-Undang Republik Indonesia No. 20 Tahun 2003 Bab I 
Pasal 1 tentang Sistem Pendidikan Nasional menyebutkan Pendidikan adalah usaha sadar dan terencana untuk mewujudkan suasana belajar dan proses pembelajaran agar peserta didik secara aktif mengembangkan potensi dirinya untuk memiliki kekuatan spiritual keagamaan, pengendalian diri, kepribadian, kecerdasan, akhlak mulia, serta keterampilan yang diperlukan dirinya, masyarakat, bangsa dan Negara. Dari ketiga pernyataan dasar hukum itu maka tiap-tiap warga Negara berhak dan wajib mendapat pendidikan bermutu secara sadar dan terencana yang ditetapkan dalam Undang-Undang tersebut.

Pendidikan merupakan suatu proses penyiapan generasi muda untuk menjelaskan kehidupan dan memenuhi tujuan hidupnya secara lebih efektif dan efesien. Dalam proses pendidikan diharapkan peserta didik secara aktif mengembangkan potensi dirinya untuk memiliki kekuatan spiritual keagamaan, pengendalian diri, kepribadian, kecerdasan dan akhlak mulia serta keterampilan yang diperlukan dirinya, masyarakat bangsa dan Negara (Azra, 2000:3). Adapun Tujuan pendidikan nasional dalam Undang-Undang Nomor 20 tahun 2003 tentang Sistem pendidikan Nasional, Bab III, Pasal 3 menyatakan bahwa tujuan pendidikan Nasional adalah membentuk manusia Indonesia yang beriman dan bertaqua kepada tuhan yang maha esa, berakhlak mulia, sehat, berilmu, cakap, kreatif, mandiri dan menjadi warga Negara yang bertanggung jawab. (Kurikulum, 2018:10).

Pendidikan karakter merupakan salah satu wacana pendidikan yang dianggap mampu memberikan jawaban atas kebuntuan dalam sistem pendidikan Indonesia di era sekarang ini. Perpres No 87 tahun 2017 tentang pendidikan karakter dimana pendidikan karakter menekankan aspek afektif dan pisikomotor tanpa mengabaikan aspek yang lain. Permendikbud No 20 Tahun 2018 tentang penguatan pendidikan karakter (PPK) dinyatakan bahwa penguatan pendidikan karakter (PPK) adalah gerakan pendidikan di bawah tanggung jawab satuan pendidikan untuk memperkuat karakter peserta didik melalui harmonisasi olah hati, olah rasa, olah pikir dan olah raga dengan pelibatan dan kerja sama antara satuan pendidikan, keluarga dan masyarakat sebagai dari Gerakan Nasional Revolusi Mental (GNRM). (Ahmad, 2010:10).

Pentingnya pendidikan karakter untuk segera dikembangkan dan diinternalisasikan, baik dalam dunia pendidikan formal maupun dalam pendidikan non formal tentu beralasan, karena memiliki tujuan yang cukup mulia bagi bekal kehidupan peserta didik agar senantiasa siap dalam merespon segala dinamika kehidupan dengan penuh tanggung jawab. Memang tidak dapat dipungkiri bahwa sudah sangat mendesak pendidikan karakter diterapkan di dalam lembaga pendidikan, karena pendidikan karakter bukan hanya tanggung jawab guru, tapi juga semua stake holder pendidikan harus terlibat dalam rangka mengembangkan pendidikan karakter ini, bahkan pemangku kebijakan harus menjadi teladan terdepan. Sebagai seorang guru harus bekerja secara profesional, memberikan pelayanan yang optimal kepada peserta didiknya, dan bekerja dengan penuh kesabaran dalam membawa peserta didiknya menuju citacita pendidikan. Hal tersebut juga sebagaimana ditekankan dalam ajaran Agama.

Agama merupakan salah satu hal mendasar dalam kehidupan manusia. Dalam Pancasila poin pertama yaitu "Ketuhanan Yang Maha Esa". Sila pertama ideologi nasional negara ini, Pancasila, menyatakan keyakinan kepada satu Tuhan. Kita wajib setia kepada bangsa dan ideologi Pancasila. Kemudian Undang-Undang Dasar Negara Republik Indonesia tahun 1945 pada BAB XI menyatakan Pasal 29 (1) Negara berdasar atas Ketuhanan Yang Maha Esa. (2) Negara menjamin kemerdekaan tiap-tiap penduduk untuk memeluk agamanya masingmasing dan untuk beribadat menurut agamanya dan kepercayaannya itu (browsing, UUD45, 2016.)

Tujuan agama Hindu adalah "Moksartham Jagadhitaya ca iti Dharma”, yang artinya bahwa agama (dharma) bertujuan untuk mencapai kebahagiaan rohani dan kesejahteraan hidup jasmani atau kebahagiaan secara lahir dan bathin. Tujuan ini secara rinci disebutkan di dalam Catur Purusa Artha, yaitu empat tujuan hidup manusia, yakni Dharma, Artha, Kama dam Moksa, yang dirumuskan dalam kitab suci weda 
sejak diwahyukan.

Weda adalah kitab suci Agama Hindu, di mana didalam Weda banyak mengajarkan tentang bagaimana cara umatnya untuk mendekatkan diri kepada tuhan. Sumber ajaran agama Hindu adalah kitab suci Weda, yaitu kitab yang berisikan ajaran kesucianyang diwahyukan oleh Hyang Widhi Wasa melalui para Maha Rsi. Weda merupakan jiwa yang meresapi seluruh ajaran Hindu, laksana sumber air yang mengalir terus melalui sungai-sungai yang amat panjang dalam sepanjang abad.

Weda adalah sabda suci atau wahyu Tuhan Yang Maha Esa, untuk menuntun umatnya agar mencapai tujuan agama Hindu yang dapat ditempuh dengan berbagai jalan seperti yang terdapat dalam ajaran Catur Guru. Dalam perspektif Hindu, pendidikan dimaknai tidak semata-mata terbatas sebagai kegiatan belajar mengajar saja, akan tetapi lebih jauh diartikan sebagai proses pematangan dan pendewasaan untuk mewujudkan manusia yang lebih manusiawi, pembentukan karakter, watak atau kepribadian sebagai salah satu tujuan pendidikan sangat penting terkait dengan keluaran (out put) peserta didik seperti yang diharapkan oleh orang tua, guru/pemerintah dan masyarakat.

Agama Hindu mengajarkan proses pendidikan yang berjenjang baik formal, non formal dan informal. Pendidikan formal sistem pendidikan persekolahan, pendidikan non formal paket pendidikan berjangka pendek dan pendidikan informal adalah jalur pendidikan keluarga dan lingkungan. Hal ini juga sebagaimana ditekankan dalam ajaran Agama Hindu yaitu ajaran Catur Guru bahwa pendidikan harus dilakukan dalam lembaga, keluarga, sekolah, dan masyarakat.

Pendidikan di era globalisasi sekarang ini di Indonesia seakan tidak hentinya menuai kritikan dari berbagai kalangan karena dianggap tidak mampu melahirkan alumni yang berkualitas. Pendidikan disekolah belum sepenuhnya menghasilkan insan-insan terdidik dan beretika dalam pergaulan di lingkungan keluarga, sekolah dan masyarakat meskipun secara sistematik atau terstruktur pendidikan disekolah sudah dijalankan dengan perencanaan, pelaksanaan dan evaluasi dengan matang.
Beragkat dari hasil observasi awal yang dilakukan di SMP Negeri Satu Atap Tianyar Tengah terdapat beberapa masalah moral peserta didik antara lain : (1) dalam pelaksanaan sembahyang yaitu tri Sandya masih banyak yang bercanda, (2) prilaku peserta didik yang berani melawan dan menghina guru, (3) perkelahian antar teman sehingga berdampak pada orang tua/wali peserta didik dalam penyelesaianya bahkan sampai ke kantor polisi, (4) merusak fasilitas milik pemerintah seperti kaca jendela, pintu dll, (5) pencurian dan perusakan barang milik temanya, (6) menyontek saat ulangan dan tugas rumah (PR) dikerjakan oleh temanya (pengakuan siswa langsung), (7) kurangnya kesadaran peserta didik terhadap kebijakan pemerintah (8) berpakian tiadak selayaknya menujukan sebagai peserta didik (Parna, wawancara 2 Februari 2018 dan dokumen buku pembinaan siswa)

Kompleksitas permasalahan tersebut di atas sangat menarik untuk dibedah, maka melalui penerapan pembelajaran ajaran Agama yaitu ajaran Catur Guru di sekolah sangat tepat dilaksanakan dalam penguatan karakter peserta didik di SMP Negeri Satu Atap Tinyar Tengah, karena ajaran Catur Guru menekankan kesadaran diri sendiri peserta didik yang bersangkutan untuk menghormati orang tua, guru, pemerintah dan Tuhan dengan menekankan tersebut akan membangun hidup yang saling menghargai, seimbang dan harmonis serta penuh dengan rasa syukur sehingga dapat mewujudkan tujuan pendidikan nasional dan tujuan pendidikan agama hindu.

Konsep ajaran Catur Guru dalam proses pendidikan dapat memberikan suatu pengaruh terhadap sikap dan hasil belajar, karena dapat menumbuhkan sikap saling menghormati dan saling menghargai dengan penuh rasa syukur, maka akan terwujud kehidupan yang saling menghargai, seimbang dan harmonis, taat terhadap orang tua, taat terhadap guru, pemerintah dan taat pada Tuhan melalui ajaran agama.

\section{METODE PENELITIAN}

Jenis data yang penelitian gunakan adalah jenis data kualitatif dengan pendekatan 
deskriptif. Metode penelitian kualitatif sering disebut metode penelitian naturalistik karena penelitiannya dilakukan pada kondisi yang alamiah (natural setting). Yang bersumber dari data primer dan data sekunder, dengan teknik pengumpulan data yang digunakan adalah observasi, wawancara, dan studi dokumen, serta instrumen yang digunakan berupa pedoman wawancara yang dilengkapi dnegan tape recorder atau alat perekam dan kamera (android), alat tulis dan laptop.

\section{PEMBAHASAN}

\subsection{Pentingnya Pembelajaran Ajaran Catur Guru}

\section{a. Mengatasi Degradasi Moral}

Degradasi moral terjadi pada masa remaja, karena masa remaja adalah masa yang paling sensitif dan penting dalam kehidupan manusia. Masa remaja bisa juga di sebut masa yang penting dan berbahaya. Lingkungan merupakan peranan penting dalam pengembangan nilai dan moral. Seiring pengembangan zaman, kehidupan remaja saat ini berbeda dengan remaja pada masa lalu. Banyak faktor yang mempengaruhi terhadap nilai dan moral remaja seperti faktor lingkungan yang mencakup aspek psikologis, sosial, budaya dan fisik kebendaan, baik yang terjadi di keluarga, sekolah, maupun masyarakat. Selain itu juga kondisi psikologis, pola interaksi, pola kehidupan beragama, berbagai sarana rekreasi yang tersedia didalam lingkungannya akan berpengaruh juga terhadap perkembangan nilai dan norma tersebut.

Remaja yang tumbuh dan berkembang pada lingkungan keluarga, sekolah dan masyarakat yang kondusif yang penuh rasa aman secara psikologis, pola ineraksi yang demokratis, penuh kasih sayang dan religius dapat diharapkan berkembang menjadi remaja yang berbudi luhur, moralitas tinggi, serta sikap dan perilaku yang terpuji. Sedangkan apabila seorang remaja tumbuh dalam kondisi lingkungan keluarga, sekolah, dan masyarakat yang tidak kondusif seperti kondisi psikologis yang penuh dengan konflik, pola interaksi yang tidak jelas, pola asuh yang tidak berimbang, dan kurang religius maka dikhawatirkan akan membentuk remaja yang tidak memiliki nilai-nilai luhur, moralitas tinggi, dan sikap terpuji.

Selain itu ada juga beberapa faktor lain yang memengaruhi penurunan nilai moral remaja, seperti longgarnya pegangan terhadap agama, kurang efektifnya pembinaan moral yang dilakukan oleh rumah tangga, sekolah maupun masyarakat, ingin mengikuti trend, himpitan ekonomi yang membuat para remaja stress, kurangnya pendidikan Agama dan budi pekerti. Kaitanya dengan penelitian ini karena masa SMP merupakan masa remaja, maka pembelajaran ajaran Catur Guru menjadi sangat penting diberikan kepada peserta didik dalam penguatan karakter di SMP Negeri Satu Atap Tianyar Tengah sehingga mnjadi manusia yang seutuhnya.

\section{b. Pendidikan untuk Meningkatkan Kualitas SDM}

Sumber daya manusia (SDM) dapat meningkat melalui pendidikan. Pendidikan menurut Undang-Undang No 20 Tahun 2003 tentang sisitem Pendidikan Nasional adalah usaha sadar dan terencana untuk mewujudkan suasana belajar dan proses pembelajaran agar peserta didik secara aktif mengembangkan potensi dirinya untuk memiliki kekuatan spiritual keagamaan, pengendalian diri, kepribadian, kecerdasan, akhlak mulia, serta ketrampilan yang diperlukan dirinya, masyarakat, bangsa dan negara. Pendidikan yang baik tidak terlepas dari seorang pendidik atau guru. Oleh karenanya diperlukan profesionalisme dalam mengajar.

Berdasarkan hasil wawancara dengan kepala sekolah dan Operator Sekolah, Semenjak SMP Negeri Satu Atap Tianyar Tegah didirikan pada tahun 2006 yang masih tergolong sangat muda namun sudah menunjukan prestasi yang menjulang, dengan usia yang muda tersebut menunjukan latar belakang pndidikan masyarakat disana hanya beberapa yang memiliki pendidikan sarjana, hampir $70 \%$ orang tua peserta didik di SMP Negri Satu Atap Tianyar Tengah tidak tamat SD, sehingga dukungan untuk mendidik anak-anak hanya bertumpu atau mengandalkan pendidikan di sekolah saja Parna, Winantra, wawancara, 11 Agustus 2018).

Berdasarkan dari pemamparan di atas, latar belakang pendidikan orang tua siswa dan 
keterbatasan tenaga pendidik yang menyebabkan kurang maksimal dalam mendidik anak yang menjadi salah satu factor pentingnya penerapan ajaran Catur Guru diberikan kepada peserta didik di SMP Negeri Satu Atap agar mampu mempengaruhi lingkungan masyarakat bahwa pendidikan agama sangat penting, untuk meningkatkan sumber daya manusia (SDM), dengan menyeimbangkan kecerdasan intelektual, emosional dan spiritual sehingga menjadi anak yang berkarakter.

\section{c. Meningkatkan Kualitas Lingkungan Sosial}

Lingkungan sosial merupakan salah satu faktor yang dapat mempengaruhi seseorang atau kelompok untuk dapat melakukan sesuatu tindakan serta perubahan-perubahan perilaku setiap individu. Lingkungan sosial yang kita kenal antara lain lingkungan keluarga, lingkungan teman sebaya, dan lingkungan tetangga. Keluarga merupakan lingkungan sosial yang pertama kali dikenal oleh individu sejak lahir. ayah, ibu, dan anggota keluarga, merupakan lingkungan sosial yang secara langsung berhubungan dengan individu, sedangkan masyarakat adalah lingkungan sosial yang dikenal dan yang mempengaruhi pembentukan kepribadian anak, yang salah satu diantaranya adalah teman sepermainan.

Lingkungan Sosial menurut Stroz (1987:76) meliputi "semua kondisi-kondisi dalam dunia yang dalam cara-cara tertentu mempengaruhi tingkah laku seseorang, termasuk pertumbuhan dan perkembangan atau life processe yang dapat pula dipandang sebagai penyiapan lingkungan (to provide environment) bagi generasi yang lain. Situasi lingkuan peserta didik sangat mempengaruhi perkembangan moral peserta didik, dimana usia peserta didik di tingkat SMP sudah tergolong remaja dengan kondisi fisikologis yang masih labil, mudah dipengaruhi oleh lingkunagn, keadaan lingkungan di sekitar sekolah yang nota bena masyarakat disana sebagian besar merantau ke kabupaten lain tentunya situasi lingkungan ditempat merantau pasti berbeda, apalagi yang merantau ke Denpasar, Badung dan lain-lain yang bekerja disektor pariwisata ketika pulang ke kampungnya saat ada upacara agama maka akan sangat mudah mempengaruhi perkembangan peserta didik di SMP Negeri Satu Atap Tianyar Tengah.

Seperti yang kita ketahui Bali merupakan daerah pariwisata, sehingga budaya-budaya dari berbagai Negara akan berinteraksi saling mempengaruhi, budaya barat begitu mudahnya berkembang seperti dari cara berpakaian, sikap sopan santun sehingga budaya asli kita semakin dilupakan. Pengaruh-pengaruh itulah yang terjadi di lingkungan SMP Negeri Satu Atap Tianyar Tengah, seperti yang disampaikan oleh I Ketut Wangun (wawancara tanggal 12 Agustus) beliau adalah guru kontrak yang sekaligus mantan kepala dusun pedahan kaja, beliau tahu persis situasi masyarakatnya, ketika musim libur akhir semester atau akhir tahun, bagi orang tuanya yang bekerja dibidang pariwisata maka anaknya akan diajak ikut merantau, setelah kembali ditemukan ada yang berbeda, dari segi penampilan, sikap dan tingkahlakunya, itu menunjukan bahwa lingkungan sangat berpengaruh terhadap perubahan sikap moral anak.

Berdasarkan pemaparan di atas perlunya pembelajaran agama untuk mempersiapkan dan meningkatkan kepercayaan diri peserta didik sangat penting agar tidak mudah dipengaruhi oleh hal-hal yang buruk, apalagi dengan trend yang sekarang ini dengan istilah "Kids zaman now" sesuatu yang viral sangat mudah untuk diikuti tanpa memandang hal tersebut bermoral atau tidak, maka sangat penting penerapan pembelajaran ajaran Catur Guru diberikan kepada peserta didik untuk penguatan karakter peserta didik di SMP Negeri Satu Atap Tianyar Tengah sehingga berdampak pada generasi lingkungan social yang berkarakter.

\subsection{Proses Pembelajaran Ajaran Catur Guru Dalam Penguatan Karakter Peserta Didik}

Paparan hasil penelitian tentang proses pembelajaran ajaran Catur Guru dalam penguatan karakter peserta didik di SMP Negeri Satu Atap Tianyar Tengah Tahun Pelajaran 2018/2019 dapat disusun menjadi tiga tahapan yaitu; 1) Persiapan Guru Sebelum Melaksanakan 
Pembelajaran, 2) Kegiatan guru selama proses pembelajaran, 3 Model dan metode yang diterapkan dan 4) Evalusi. Adapun kegiatan guru sebelum melaksanakan pembelajaran maka guru tersebut harus mempersiapkan beberapa hal seperti: 1). Menganalisis Kurikulum dan kalender pendidikan. 2). Membuat program tahunan dan semester. 3). Membuat Rencan Program Pembelajaran. 4). Membuat administrasi pembelajaran lainya seperti jadwal, membuat KKM, agenda harian, daftar nilai, daftar hadir siswa dan lain-lainya.

Kemudian kegiatan guru selama proses pembelajaran yang dilaksanakan dengan bentuk pembelajaran di dalam kelas dimana terjadinya interaksi antara pendidik dengan peserta didik di dalam ruangan kelas yang diawali dengan apersepsi, kegiatan inti dan evaluasi. Kemudian yang kedua adalah pross pembelajaran diluar kelas seperti saat upacara bendera, darmawacana setelah persembahyangan purnama, tilem dan hari raya saraswati, dan pengumuman sewaktu-waktu setelah tri sandya.

Model pembelajaran dan metode yang diterapkan guru saat proses pembelajaran adalah Model Pembelajaran Kontekstual (CTL), model pembelajaran berbasis masalah dan model pembelajaran pemberian tugas. Kemudian metode yang diterapkan adalah metode ceramah, metode diskusi. Setelah guru mempersiapkan segala bentuk administrasi dan proses pembelajaran maka tidak terlepas dari evalusiyang dilakukan oleh guru untuk mengukur tingkat keberhasilan baik pendidik maupun peserta didik sesuai dengan pandangan Norman E. Gronlund (1976:18) merumuskan pengertian evaluasi sebagai berikut: "Evaluation is a systematic process of determining the extent to which instructional objectives are achieved by pupils". (Evaluasi adalah suatu proses yang sistematis untuk menentukan atau membuat keputusan sampai sejauh mana tujuan-tujuan pengajaran telah dicapai oleh siswa).

Berdasarkan dari pemaparan di atas evaluasi yang dilaksanakan di SMP Negeri Satu Atap Tianyar Tengah, sesuai dengan tujuan dan fungi evaluasi proses pembelajaran ajaran Catur Guru dalam penguatan karakter peserta didik di SMP Negeri Satu Atap Tianyar Tengah dilaksanakan hanya dengan bentuk tes tertulis baik setiap pertemuan, tengah semester dan penilaian akhir semester serta ujian, penilaian dalam bentuk tes tertulis tersebut digunakan untuk mengukur atau menilai sampai dimana keefektifan pengalaman-pengalaman mengajar, kegiatankegiatan belajar, dan metode mengajar yang digunakan. Sedangkan evaluasi yang lain secara khusus tidak ada (Soma, Wawancara 21 Agustus 2018).

\subsection{Implikasi Pembelajaran Ajaran Catur Guru Dalam Menguatkan Karakter Peserta Didik}

Implikasi pembelajaran ajaran catur guru untuk menguatkan peserta didik di SMP Negeri Satu Atap Tianyar Tengah antara lain, 1). Terjadinya perubahan sikap religius peserta didik yaitu perubahan dalam pelaksanaan Tri Sandya dan perubahan dalam persembahyangan purnama, tilem dan hari Saraswati 2). Terjadi Perubahan sikap nasionalis yaitu perubahan sikap disiplin peserta didik, perubahan terhadap prestasi peserta didik dan kecintaan tanah air semakin kuat. 3). Terjadi perubahan sikap mandiriyaitu perubahan dalam etos kerja (Kerja Keras) peserta didik dan perubahan dalam daya juang peserta didik. 4). Terjadi perubahan sikap gotong royong peserta didik yaitu perubahan dalam sikap kerelawanan atau gotong royong (Ngayah di Pura) dan perubahan dalam sikap anti kekerasan peserta didik. 5). Terjadi perubahan sikap integritas yaitu perubahan dalam sikap kejujuran peserta didik dan perubahan dalam sikap rasa tanggung jawab peserta didik.

\section{PENUTUP}

Pentingnya pembelajaran ajaran Catur Guru diberikan kepada peserta didik, yaitu untuk mengatasi degradasi moral yang terjadi pada dunia pendidikan sekarang ini, Pendidikan untuk meningkatkan kualitas SDM, untukmeningkatkan kualitas lingkungan sosial, untuk meningkatkan kesejahteraan sosial ekonomi.

Proses pembelajaran catur guru dimulai dari persiapan guru sebelum melaksanakan proses pembelajaran, yaitu mempersiapkan dan melengkapi administrasi pembelajaran serta alat praga atau media pembelajaran, dan proses 
pembelajaran yang dilakukan di dalam kelas, dan proses pembelajaran yang dilakukan diluar kelas yaitu melalui pembinaan-pembinaan saat upacara bendera dan setelah selesai tri sandya sebelum mamasuk kelas dan darma wacana yang dilaksanakan setelah persembahyangan hari raya saraswati, purnama dan tilem. Dengan berbagai model pembelajaran seperti model pembelajaran kontekstual, model pembelajaran berbasis masalah dan model pembelajaran pemberian tugas serta menerapakan berbagai metode seperti metode ceramah dan metode diskusi sehingga proses pembelajaran peserta didik di SMP Negeri Satu Atap Tianyar Tengah menjadi menyenangkan. Sebagai alat ukur untuk menentukan keberhasilan dalam pembelajaran dengan melakukan evaluasi dalam bentuk tes.

Implikasi pembelajaran ajaran catur guru untuk menguatkan karakter peserta didik di SMP Negeri Satu Atap Tianyar Tengah, melalui sikap hormat dan bhakti peserta didik terhadap ajaran catur guru (Guru Swadyaya, Guru Rupaka, Guru Pengajian, guru wisesa), dapat mewujudkan nilai penguatan pendidikan karakternya (Religius, Nasionalis, Mandiri, Gotong Royong dan Integritas).

\section{DAFTAR PUSTAKA}

Ahmad, 2014. Tt "Evaluasi Pendidikan" tersedia dalam URL. https://www.eurekapendidikan.com /2014/10/ pengertian-dan-Peranan -evaluasi -pembelajaran.pdf. diunduh pada tanggal 19 Agustus 2018

Azra, A. 2000. Pendidikan Agama; Tradisi Moderenisasi Menuju Milineum Baru. Jakarta : PT. Logos Wacana Ilmu.

Gronlund Norman E, 2013. "Pengertian Evaluasi"tersedia dalam URL www.areabaca.com/2013/06/ pengertian-evaluasi-pendidikan.html di unduh tanggal 8 Agustus 2018

kbbi, 1996. Tt “Pengertian sosial”. Tersedia dalam URL: http://kbbi.blogspot.com, akses tanggal 7 Agustus 2018

Licona Thomas. 1991. Educating For Character. New York: Bantam Books

Nasution, S. 2003. Metodologi Penelitian Naturalistik Kualitatif. Bandung : Tarsito

Pendit, 2007. Bagavad Gita. Surabaya: Paramita

Titib, 2006. Keutamaan Manusia dan Pendidikan Budi Pekerti, Surabaya: Paramita

Walgito, Bimo. 2005. Bimbingan dan Konseling di Sekolah. Yogyakarta: Andi

2003. Undang-Undang Republik Indonesia Nomor 20 Tahun 2003 Tentang Sistem Pendidikan Nasional. Jakarta: Departemen Pendidikan Nasional Republik Indonesia.

2005. Undang-Undang Republik Indonesia Nomor 14 Tahun 2005 Tentang Guru dan Dosen. Jakarta: Departemen Pendidikan Nasional Republik Indonesia.

2017. Peraturan Pemerintah Perpres No 87 tahun 2017 tentang pendidikan karakter. Jakarta:

Departemen Pendidikan Nasional Republik Indonesia

2018. Permendikbud No 20 Tahun 2018 tentang penguatan pendidikan karakter (PPK). Jakarta:

Departemen Pendidikan Nasional Republik Indonesia 